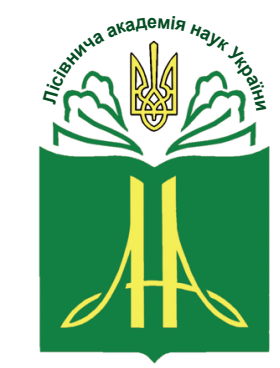

Forestry Academy of Sciences of Ukraine
Наукові праці Лісівничої академії наук України Proceedings of the Forestry Academy of Sciences of Ukraine http://fasu.nltu.edu.ua https://doi.org/10.15421/412114

Article received 2020.10.22

Article accepted 2021.06.10
ISSN 1991-606X print

ISSN 2616-5015 online

(a) $\triangle$ Correspondence author

Volodymyr P. Pasternak

pasternak65@ukr.net
Pushkinska str., 86, Kharkiv, 61024, Ukraine

УДК $630 * 5: 582.632 .2$

\title{
Розмірно-якісна структура стовбурів Quercus robur L. у деревостанах вегетативного походження Лівобережного Лісостепу України
}

\author{
В.П. Пастернак', О. А. Слиш², В. В. Назаренко
}

\begin{abstract}
Для досліджень розмірно-якісної структури деревини стовбурів Quеrсиs robur L. використано дослідні дані, зібрані в деревостанах вегетативного походження Лівобережсного Лісостепу на тимчасових пробних площах. Проаналізовано розподіл об 'єму ділових стовбурів дуба звичайного за розмірно-якісними категоріями деревини залежно від діаметра, висоти та об 'єму. Найтіснішу лінійну залежність від об 'єму стовбура в корі виявлено для абсолютних значень об'єму ділової деревини. Пошук параметрів рівнянь виконано у MS Exсеl. Систематична похибка математичних моделей виходу ділової деревини становить 1,0\%. Для отримання даних розподілу об'єму ділової деревини за класами товщини, передбачених ДСТУ 1315-1-2001, розроблено алгоритм умовного розкряжування модельних дерев, який базується на апроксимаџї твірної поверхні стовбура за допомогою математичної моделі функиї Riemer-Gadow-Sloboda. Розмірну структуру ділової деревини узагальнено за методикою, що базується на встановленні закономірностей розподілу об'єму за класами товщини у відносних величинах. Виявлено тісну залежність (коефіuієнт детермінаиії моделей $R^{2}=0,68-0,82$ ) відносних величин розмірної структури від діаметра модельних дерев на висоті 1,3 м. Порівняння поданих нормативів з даними розробки лісосік рубок головного користування 2019-2020 рр. показало, щзо характер розподілу деревини за класами товщини є подібним з незначними відхиленнями. Розроблені за новими стандартами табличі забезпечують прогнозування розподілу об'єму ділової деревини ділових стовбурів дуба звичайного за класами товщини, за серединним діаметром лісоматеріалів без кори залежно від діаметра на висоті 1,3 м.

Ключові слова: лісоматеріали круглі; класи товщиини; розкряжування; твірна стовбура.
\end{abstract}

Вступ. Одним із важливих завдань виробничої діяльності лісогосподарських підприємств в Україні $є$ визначення структури лісосічного фонду, тобто розподілу деревини на ділову, дров'яну та відходи, а ділової - за класами розмірів та якості. За нинішніх умов частина нормативної бази, яку розробляли у попередні роки для вирішення зазначених завдань, частково втратила актуальність. Це зумовле- но насамперед тим, що з 01.01.2021 р. в Україні набув чинності ДСТУ EN 1316-1:2019, який встановлює вимоги до круглих лісоматеріалів дуба та бука за якістю. Втратили чинність стандарти, що регламентують обмір, визначення об'ємів і класифікацію за розмірами лісоматеріалів круглих. Так, зі скасуванням ГОСТ 9462-88 (Лесоматериалы круглые лиственных пород. Технические условия, 1988) та

\footnotetext{
Пастернак Володимир Петрович - академік Лісівничої академії наук України, доктор сільськогосподарських наук, професор. Український науково-дослідний інститут лісового господарства та агролісомеліорації ім. Г.М. Висоцького, вул. Пушкінська, 86, Харків, 61024, Україна. Тел.: +38-057-707-80-44. E-mail: pasternak65@ukr.net ORCID: https://orcid.org/0000-0003-1346-1968

2 Слиш Олександр Анатолійович - кандидат сільськогосподарських наук, лісничий Новомутинського лісництва ДП Конотопське лісове господарство, вул. Конотопських партизан, 97, м. Конотоп, Сумська обл., 41605, Україна. Тел.: +38 (05447) 6-62-38 E-mail: slysh_oleksandr@ukr.net

Назаренко Віталій Васильович - кандидат сільськогосподарських наук, доцент кафедри лісоуправління, лісоексплуатації та безпеки життєдіяльності. Харківський національний аграрний університет ім. В. В. Докучаєва, «Докучаєвське - 2», Харківський район, Харківська обл., 62483, Україна. Тел.: +38-0572-99-76-80 E-mail: flg@knau.kharkov.ua
} 
ГОСТ 2708-75 (Лесоматериалы круглые. Таблицы объемов, 1975) повною мірою введено стандарти ДСТУ 4020-2-2001 (Лісоматеріали круглі та пиляні. Методи обмірювання та визначення об'ємів, 2001) та ДСТУ ЕN 1315-1-2001 (Класифікація за розмірами, 2002). Замість скасованих ТУУ 56.19695 (Деревина дров'яна для технологічних потреб, 1995) та ГОСТ 3243-88 (Дрова. Технические условия, 1989) введено ТУУ-00994207-005:2018 (Деревина дров'яна. Класифікація, облік, технічні вимоги, 2018), які класифікують дров'яну деревину промислового та непромислового використання за якістю та розмірами. 3 огляду на це потребують удосконалення нормативи, які розробляли на основі скасованих стандартів.

Досліджуючи дубові деревостани Правобережного Придніпровського Лісостепу, В.Б. Биченко (2019) встановив, що відносні значення показників розмірної структури ділової деревини найтісніше корелюють із діаметром стовбура. Форма цієї залежності нелінійна, доволі складна та апроксимується системою рівнянь. За результатами досліджень складено таблиці розподілу об'єму ділових стовбурів дуба та розподілу ділової деревини ділових стовбурів дуба за класами товщини за серединним діаметром без кори (Биченко, 2019). Водночас у Правобережному Лісостепу України переважають дубові деревостани насіннєвого походження, а в Лівобережному - вегетативного. У «Лісотаксаційному довіднику» (2020) наведено таблиці розподілу об'єму ділових стовбурів за класами та підкласами товщини.

Для моделювання розмірно-якісної структури стовбурів Quercus robur L. дослідники (В.Б. Биченко, В.В. Биченко, Миронюк, 2018; В.Б. Биченко, Миронюк, 2019) пропонують використовувати математичну модель А. Kozak (2004). Польські вчені (Socha, Netzel \& Cywicka, 2020) порівняли такі методи для моделювання форми стовбура: рівняння твірної, регресійні моделі та штучна нейронна мережа (ШНМ). Як контроль використали відкаліброване рівняння змінної експоненти, запроваджене А. Козаком (Kozak, 2004). Модель на основі нейронної мережі дає змогу з високою точністю оцінити діаметр стовбура на будьякій висоті. Додатковою перевагою $є$ можливість їі вдосконалення, наприклад, збільшенням навчального набору, кращим узгодженням структури моделі до топології фігури виду, зміни нелінійної функції переходу або зміни параметрів навчання. Отже, ШНМ є універсальним інструментом для побудови моделей форми та об'єму стовбура. Вони дають змогу будувати моделі, які дуже добре відповідають емпіричним даним і дозволяють визначати діаметр без систематичних помилок на будь-якій висоті стовбура. Тому ШНМ можна використовувати для побудови місцевих моделей форми та об'єму стовбура, що використовують у лісовій практиці (Socha, Netzel \& Cywicka, 2020).

Використовуючи дані вимірювань стовбура, M. Castle et al. (2017) кількісно визначили міжвидо- ві та регіональні зміни у формі та пошкодженні стовбура, пов'язали потенційний вихід пиломатеріалів із розміром дерева, формою і вадами, та порівняли ефективність із загальноприйнятою системою класифікації та показниками якості стовбура. Було встановлено значні відмінності як у формі стовбура, так і в пошкодженнях видів. Спрощена система, що містить три класи, виявилася достатньою для диференціації потенціалу пиломатеріалів на окремих деревах, тоді як модель, що використовує постійний показник якості стовбура (розрахункова висота товарного пиловника), показала найкращі результати.

Враховуючи високі вимоги до точності оцінювання розмірно-якісної структури деревостанів 3 урахуванням вимог нових стандартів на лісоматеріали круглі, актуальним завданням є об'єктивне встановлення об'ємотвірних показників стовбурів, кількісних і якісних характеристик запасу дубових деревостанів вегетативного походження та розроблення системи відповідного нормативнодовідкового забезпечення.

Об'єкти і методи. Об 'єкт дослідження - деревостани Quercus robur L. вегетативного походження Лівобережного Лісостепу. Предмет дослідження - формування розмірно-якісної структури дубових деревостанів вегетативного походження Лівобережного Лісостепу України.

Мета дослідження: визначити закономірності виходу ділової деревини, дров і відходів із ділових стовбурів дуба; розробити математичні моделі цих закономірностей та на їхній основі скласти відповідні таблиці розподілу.

Дослідні дані подано за результатами обміру 256-ти ділових модельних дерев дуба на 28 тимчасових пробних площах у пристиглих, стиглих і перестиглих дубових деревостанах вегетативного походження Лівобережного Лісостепу. Додатково використано дані двох пробних площ, що закладені під керівництвом М.В. Любчича з рубкою та обмірюванням 10 ділових модельних дерев. Оскільки в Україні на сьогодні не розроблено методик класифікації стовбурів за категоріями технічної придатності (ділові, напівділові, дров'яні) з урахуванням нових стандартів на лісоматеріали, у наших дослідженнях діловими вважали дерева, з нижньої частини стовбура яких можливо заготовити діловий сортимент категорій А, В, С (ДСТУ EN 1316-1:2019) завдовжки не менше ніж 6,5 метра.

На деревах, що ростуть, вимірювали діаметри за допомогою програмно-технологічного комплексу Field-Mар. Для побудови твірної стовбура використовували функцію Riemer-Gadow-Sloboda (Riemer et al., 1995) за допомогою нелінійного регресійного рівняння через оцінювання невідомих параметрів (i, p, q) моделі. На зрубаних модельних деревах (73 шт.) вимірювали довжину стовбура від пня, висоту і діаметр пня, підраховували кількість річних шарів на пні, уточнювали визначення категорій деревини і діаметрів у корі та без кори. За наявності гнилі на пні вимірювали іï діаметр, а під час розкряжування - висоту іiї поширення. 
Класифікацію колод за якістю здійснювали як за нормативами, що діяли до 2019 р. (надалі - ГОСТ), так і за новими, які набули чинності з 2019 року. За вимогами ГОСТ 9462-88, лісоматеріали дуба встановлювали завдовжки від 3,0 м, дрова технологічні (ТУУ 56.196-95) та дрова паливні (ГОСТ 324388 - від 1,0 метра. Згідно з вимогами ДСТУ, розподіл виконували на лісоматеріали круглі завдовжки від 3,0 м (класів якості А, В (фанерний кряж) від 1 м) (ДСТУ EN 1316-1:2019), деревину дров'яну промислового і непромислового використання завдовжки від 1,0 м (ТУУ-00994207-005:2018).

Дані обробляли з використанням Field-Map Stem analyst i MS Excel. Основні статистики розподі- лу таксаційних показників модельних дерев $\left(d_{1,3}-\right.$ діаметр у корі на висоті $1,3 \mathrm{~m} ; h-$ висота; $V K-$ об'єм стовбура в корі, м³; Vділ. - об'єм ділової частини, м³; $P v d i л$. - частка ділової деревини від об'єму стовбура в корі, \%) наведено в табл. 1.

Дослідні дані охоплюють доволі широкий діапазон показників стовбурів дерев дуба за діаметром $(26,0-81,0$ см) та висотою $(19,2-35,2$ см). Коефіцієнти мінливості цих показників свідчать про достатню однорідність дослідних даних, оскільки становлять 23 та 11\% відповідно (Никитин, Швиденко, 1978). За таких умов, за даними вибірки для регіону досліджень можливе узагальнення закономірностей розподілу об’єму ділових стовбурів.

Основні статистики досліджуваних показників

Таблиия 1

\begin{tabular}{|c|c|c|c|c|c|c|c|}
\hline \multirow{2}{*}{ Показник } & \multirow{2}{*}{$d_{1,3}, \mathrm{~cm}$} & \multirow{2}{*}{$h, \mathrm{M}$} & \multicolumn{2}{|c|}{ ГОСТ } & \multicolumn{2}{|c|}{ ДСТУ } & \multirow{2}{*}{ Vк, $\mathrm{m}^{3}$} \\
\hline & & & Vділ.с & Рvділ.c & Иділ.н & Рүділ.н & \\
\hline Середнє значення, М & 43,6 & 25,8 & 1,250 & 58,6 & 1,446 & 68,1 & 1,796 \\
\hline $\begin{array}{l}\text { Середнє квадратичне } \\
\text { відхилення, } \sigma\end{array}$ & 9,99 & 2,93 & 0,791 & 10,4 & 0,863 & 8,2 & 1,001 \\
\hline Коефіцієнт мінливості, V, \% & 22,9 & 11,3 & 63,3 & 17,8 & 59,7 & 12,0 & 55,7 \\
\hline Асиметрія, А & 0,993 & 0,057 & 1,528 & $-0,393$ & 1,309 & $-1,153$ & 0,812 \\
\hline Ексцес, E & 0,940 & $-0,476$ & 2,455 & $-0,687$ & 1,531 & 1,135 & 0,493 \\
\hline
\end{tabular}

Для виявлення залежностей розподілу деревини ділових стовбурів за категоріями залежно від діаметра, висоти та об'єму стовбурів у корі було здійснено аналіз кореляційних зв'язків між цими показниками.

Для отримання даних розподілу ділової деревини за класами якості та розмірів, передбачених ДСТУ 1315-1-2001 (за серединним діаметром), застосували алгоритм умовного розкряжування модельних дерев і реалізували його у Field-Map Stem Analist. Його побудовано на основі твірної поверхні стовбура за допомогою математичної моделі функції Riemer-Gadow-Sloboda, яку було опрацьовано на цих самих дослідних даних (Слиш, Солодовник, Букша, 2014). За результатами обміру стовбурів визначали діаметр і висоту, встановлювали послідовність відрізків стовбура відповідних розмірно-якісних категорій за пріоритетом від класу якості А до дров непромислового використання. При цьому враховували встановлені вимоги до лісоматеріалів круглих: наявність вад, мінімальні (максимальні) довжини лісоматеріалів за класами якості ділової деревини, дров промислового і непромислового використання; діаметри лісоматеріалів, а також градацію за довжиною та діаметром (серединним без кори - для ділових лісоматеріалів, верхнім у корі - для дров'яних).

Об'єм ліквідної частини стовбурів обчислювали в корі та без кори послідовно, від окоренка до верхівки стовбура, згідно з вимогами до відповідного класу якості та в міру спадання пріоритетів. Якщо серединний діаметр, мінімальна довжина відрізка та/або якість стовбура не задовольняли встановлені вимоги, то призначали нижчий клас якості ділових лісоматеріалів або дров'яної деревини. Класи товщини ділової деревини встановлювали за серединним діаметром колод без кори: D1 14,5-19,4 см, D2 - 19,5-29,4 см, D3 - 29,5-39,4 cм, D4 - 39,5-49,4 cм, D5 - 49,5-59,4 cм, D6 $\geq 59,5 \mathrm{~cm}$ (Класифікація за розмірами, 2002).

Зведені дані вимірювань містять інформацію про параметри кожного сортименту, отриманого 3 конкретного модельного дерева: серединний діаметр без кори для ділових сортиментів і верхній із корою - для дров, їхню довжину та об'єм.

Дані стосовно розмірної структури ділової деревини узагальнювали за методикою, що базується на дослідженні закономірностей розподілу об'єму ділової деревини за класами товщини у відносних величинах. За результатами аналізу виявлено тісну залежність відносних показників розмірної структури деревини стовбурів від діаметра на висоті 1,3 метра. Пошук форми залежностей та обчислення параметрів рівнянь виконали в MS Excel.

Результати та обговорення. За результатами кореляційного аналізу встановлено, що фактичні значення коефіцієнтів кореляції між частками ділової деревини (Рділ.) і біометричними показниками стовбурів $€$ меншими за критичне значення, що свідчить про відсутність лінійної залежності між цими показниками (табл. 2). 
Коефіціснти кореляції між досліджуваними показниками

Таблиия 2

\begin{tabular}{|c|c|c|c|c|c|c|c|c|}
\hline \multirow{2}{*}{\multicolumn{2}{|c|}{ Показник }} & \multirow{2}{*}{$\mathrm{d}, \mathrm{cm}$} & \multirow{2}{*}{$\mathrm{h}, \mathrm{m}$} & \multicolumn{2}{|c|}{ ГОСТ } & \multicolumn{2}{|c|}{ ДСТУ } & \multirow{2}{*}{ Vк, $\mathrm{m}^{3}$} \\
\hline & & & & Vділ.с & Рділ.с & Vділ.н & Рділ.н & \\
\hline & & 1,00 & 0,68 & 0,93 & 0,10 & 0,95 & 0,07 & 0,95 \\
\hline & & & 1,00 & 0,76 & $-0,01$ & 0,81 & 0,05 & 0,72 \\
\hline \multirow{2}{*}{ ГОСТ } & Vділ. & & & 1,00 & 0,32 & 0,98 & 0,23 & 0,94 \\
\hline & Рділ. & & & & 1,00 & 0,20 & 0,76 & 0,03 \\
\hline \multirow{2}{*}{ ДСТУ } & Vділ. & & & & & 1,00 & 0,20 & 0,96 \\
\hline & Рділ. & & & & & & 1,00 & $-0,02$ \\
\hline \multicolumn{2}{|c|}{$\mathrm{V}, \mathrm{M}^{3}$} & & & & & & & 1,00 \\
\hline
\end{tabular}

Для абсолютних значень об’єму ділової деревини виявлено тісну лінійну залежність від діаметра і висоти стовбура та об’єму стовбура в корі (рис. 1).

Математичні моделі для встановлення залежності виходу ділової деревини в абсолютних величинах від об'єму стовбура в корі враховують вплив на ці показники не лише діаметра, але й висоти та форми стовбура. Залежність виходу ділової дереви- ни від об'єму стовбура описують такі лінійні рівняння:

$$
\begin{aligned}
& \text { Vділс. }=0,629 \cdot V \kappa-0,067 ; R^{2}=0,93, \\
& \text { Иділн. }=0,711 \cdot V \kappa-0,047 ; R^{2}=0,96,
\end{aligned}
$$

де $V \kappa, V \partial і л$. - об'єми стовбура в корі та ділової деревини відповідно.

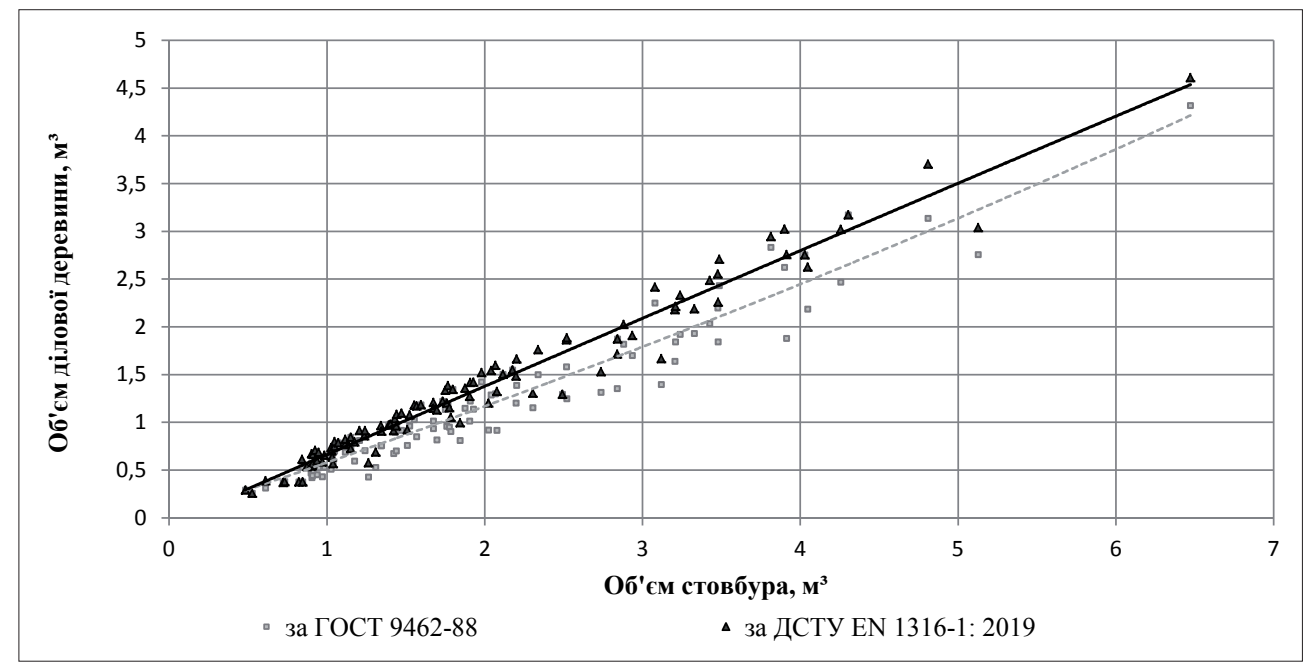

Рис. 1. Залежність виходу ділової деревини від об’єму стовбура в корі за вимогами ГОСТ і ДСТУ

Встановлено тісну залежність виходу окремих розмірних категорій деревини від діаметра на висоті 1,3 м, яку проілюстровано на рис. 2.

За результатами моделювання отримано такі рівняння:

$$
\begin{aligned}
& P_{15-19}=1645 * \mathrm{e}^{(-0,142 * \mathrm{~d})}, \quad 20<d \leq 36 ; \\
& P_{15-19}=100, \quad d=20 ; \\
& P_{20-29}=470 * \mathrm{e}^{(-0,065 * \mathrm{~d})}, \quad 36<d \leq 56 ; \\
& P_{20-29}=100-P_{15-19}, 24 \leq d \leq 28 ; \\
& P_{30-39}=-0,43 * d^{2}+37,95 * d-765,40<d \leq 56 ; \\
& P_{30-39}=100-P_{15-19}-P_{20-29} ; \\
& P_{40-49}=98,1 * \ln (d)-341,1,52<d \leq 64 ; \\
& P_{50-59}=100-P_{40-49}-P_{30-39}-P_{20-29}, 52<d \leq 64,
\end{aligned}
$$

де: $d$ - діаметр стовбура на висоті $1,3 \mathrm{~m} ; P_{15-19}$, $P_{20-29}, P_{30-39}, P_{40-49}, P_{50-59}$ - частка об'єму ділової деревини відповідного класу товщини від загального об’єму ділової деревини стовбура.

На основі розроблених математичних моделей складено таблиці розподілу об'єму ділової деревини ділових стовбурів дуба за класами товщини серединного діаметра без кори (табл. 3).

За нашими розрахунками, частки виходу ділової деревини є дещо нижчими, ніж у чинних нормативах. Так, за «Лісотаксаційним довідником» (2020) для стовбурів діаметром 40 см вихід ділової деревини становить $77,3 \%$, а за нашими даними $-68,1 \%$; для стовбурів $60 \mathrm{~cm}-77,6$ і 69,8\% відповідно.

За результатами досліджень, для дубових деревостанів вегетативного походження Лівобережно- 
го Лісостепу середній вихід ділової деревини становить 58,6\% (за ГОСТ), хоча серед модельних дерев $є$ стовбури з високою часткою ділової деревини (до 74,3\%).

\section{Таблиия 3}

Розподіл об'єму ділової деревини стовбурів Quercus robur L. за серединним діаметром колод без кори, \%

\begin{tabular}{|c|c|c|c|c|c|c|}
\hline \multirow{2}{*}{ 空 } & \multicolumn{6}{|c|}{$\begin{array}{c}\text { Клас товщини за серединним діаметром } \\
\text { без кори, см }\end{array}$} \\
\hline & D1 & $\mathrm{D} 2$ & D3 & D4 & D5 & D6 \\
\hline 20 & 100 & - & - & - & - & - \\
\hline 24 & 54 & 46 & - & - & - & - \\
\hline 28 & 31 & 69 & - & - & - & - \\
\hline 32 & 17 & 83 & - & - & - & - \\
\hline 36 & 10 & 50 & 40 & - & - & - \\
\hline 40 & 6 & 32 & 51 & 11 & - & - \\
\hline 44 & - & 21 & 55 & 24 & - & - \\
\hline 48 & - & 13 & 52 & 35 & - & - \\
\hline 52 & - & 8 & 43 & 47 & 2 & - \\
\hline 56 & - & 5 & 27 & 54 & 14 & - \\
\hline 60 & - & - & 4 & 61 & 35 & - \\
\hline 64 & - & - & - & 44 & 48 & 8 \\
\hline
\end{tabular}

Збільшення середнього значення частки виходу ділової деревини від 58,6\% (за ГОСТ) до 68,0\% (за ДСТУ) зафіксовано переважно у стовбурів із мінімальною протяжністю ділової частини. Вихід ділової деревини для таких стовбурів збільшився внаслідок зарахування об'єму частини сортиментів, віднесених за ГОСТ до дров технологічних, до якісної категорії D круглих лісоматеріалів ділової деревини за новими ДСТУ. Для стовбурів, протяжність ділової частини яких за ГОСТ перевищувала 15 м, у дров'яній частині, відповідно до ДСТУ, визначали переважно дров'яну деревину.

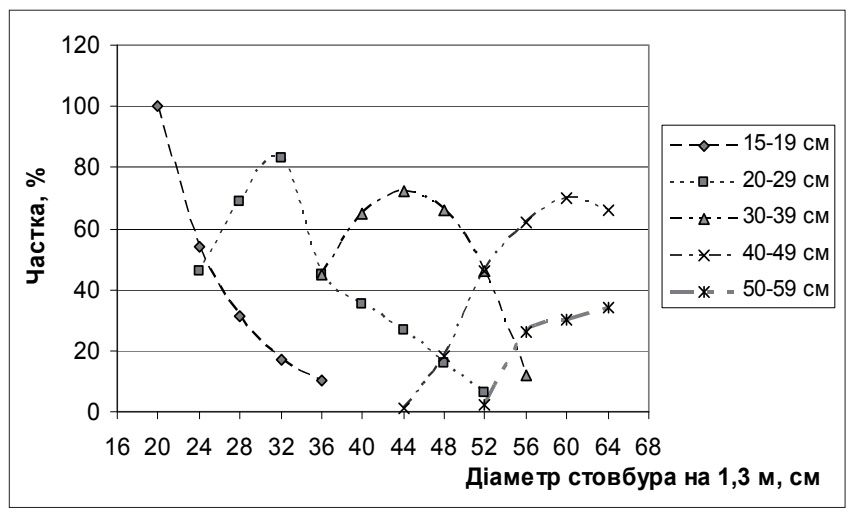

Рис. 2. Розподіл ділової деревини за класами товщини залежно від діаметра стовбура

Для перевірки розроблених нормативів використано дані розробки лісосік рубок головного користування 2019-2020 рр. у ДП «Конотопське ЛГ» і ДП «Краснопільське ЛГ». При цьому порівнювали вихід деревини за класами товщини (табл. 4).

Порівняння розмірної структури деревини

Таблиця 4

\begin{tabular}{|c|c|c|c|c|c|c|c|c|c|c|c|c|c|}
\hline \multirow{3}{*}{$\begin{array}{c}\text { № } \\
\text { 3.П. }\end{array}$} & \multirow{3}{*}{ Кв. } & \multicolumn{6}{|c|}{ Дані обліку лісопродукції } & \multicolumn{6}{|c|}{ За таблицею 3} \\
\hline & & \multicolumn{5}{|c|}{ класи товщини } & \multirow{2}{*}{$\begin{array}{c}\text { разом } \\
\text { ділової }\end{array}$} & \multicolumn{5}{|c|}{ класи товщини } & \multirow{2}{*}{$\begin{array}{r}\text { разом } \\
\text { ділово }\end{array}$} \\
\hline & & D2 & D3 & D4 & D5 & D6 & & $\mathrm{D} 2$ & D3 & D4 & D5 & D6 & \\
\hline 1 & 63 & 31,4 & 53,1 & 25,9 & 3,5 & 1,0 & 115,5 & 29,5 & 46,1 & 26,7 & 3,6 & 1,1 & 108,7 \\
\hline 2 & 80 & 71,2 & 106,1 & 34,2 & 0,7 & - & 212,4 & 64,8 & 91,6 & 32,2 & 0,8 & - & 189,4 \\
\hline 3 & 23 & 21,0 & 32,7 & 16,5 & 6,6 & 0,9 & 77,7 & 19,3 & 33,4 & 18,6 & 6,9 & 0,8 & 79,0 \\
\hline 4 & 64 & 72,1 & 161,4 & 41,2 & 4,6 & - & 279,3 & 89,3 & 145,9 & 31,3 & 4,9 & - & 283,9 \\
\hline 5 & 85 & 40,4 & 84,5 & 29,2 & 7,0 & 1,6 & 162,7 & 44,3 & 71,0 & 31,4 & 6,7 & 0,9 & 154,3 \\
\hline
\end{tabular}

Порівняння свідчить, що характер розподілу за класами товщини є подібним. За таблицями, зазвичай, дещо вищою є частка лісоматеріалів круглих класів товщини D2 і D5 (на 2,1 і 4,8\% відповідно), і меншою - у класі товщини D3 (у середньому на 10,1\%). Вихід ділової деревини за таблицями у середньому є меншим на $3,7 \%$, що може бути пов'язано з особливостями обліку ділової деревини за серединним діаметром, а також тим, що встановлені закономірності стосуються лише ділових стовбурів. Як зазначено раніше, із запроваджен- ням в Україні стандартів на лісоматеріали, що гармонізовані з європейськими вимогами, чинні нормативи розподілу стовбурів за категоріями технічної придатності (ділові, напівділові та дров'яні) не повною мірою відповідають їхньому змісту. За новими стандартами певну частину напівділових i дров'яних стовбурів буде віднесено до категорії ділових та/або напівділових за рахунок колод категорії D, які раніше класифікували як «технологічна сировина виробничо-технічного призначення». Тобто загальне зростання запасу ділової деревини 
на певній лісосіці буде спричинене збільшенням ї̈ виходу зі стовбурів усіх категорій.

Висновки. Встановлено тісну лінійну залежність абсолютних значень об'єму ділової деревини від діаметра та висоти стовбура $(\mathrm{r}=0,76-0,95)$. Найтіснішу лінійну залежність встановлено для абсолютних значень об'єму ділової деревини від об'єму стовбура в корі $(\mathrm{r}=0,94-0,96)$. Така залежність враховує вплив на вихід якісних категорій деревини не лише діаметра і висоти, але й інших біометричних показників стовбура. Збільшення середнього значення частки виходу ділової деревини від 58,6\% (за ГОСТ) до 68,0\% (за ДСТУ) зафіксовано переважно у стовбурів із мінімальною протяжністю ділової частини. Вихід ділової деревини для таких стовбурів збільшився внаслідок переходу об'єму частини сортиментів, віднесених за ГОСТ до дров технологічних, до якісної категорії D круглих лісоматеріалів ділової деревини за новими ДСТУ.

Розроблені таблиці розподілу дають змогу прогнозувати вихід ділової деревини для дубових деревостанів вегетативного походження Лівобережного Лісостепу з достатньою точністю за новими європейськими стандартами та здійснювати іiі розподіл за класами товщини. Встановлені закономірності стосуються ділових стовбурів, тоді як особливості виходу ділової деревини з напівділових і дров'яних стовбурів потребують додаткових досліджень.

\section{Список літератури}

Биченко В.Б. (2019). Моделювання розмірноякісної структури стовбурів дуба звичайного за європейськими стандартами. Науковий вісник НЛТУ України, 29(7), 90-95. [Bychenko, V. B. (2019). Modeling of Size and Quality Structure of Common Oak Tree Stem in Compliance with European Standards. Scientific Bulletin of Ukrainian National Forestry University, 29(7), 90-95. https://doi.org/10.15421/40290718] (in Ukrainian)

Биченко В.Б., Биченко В. В, Миронюк В. В. (2018). Моделювання об'єму ділових сортиментів дуба звичайного з використанням рівнянь твірної деревних стовбурів. Науковий вісник НУБіП України. Серія: Лісівництво та декоративне садівниитво, 288, 6-17. [Bychenko, V.B., Bychenko, V.V., \& Myroniuk, V.V. (2018). Modelling roundwood merchantable volumes for common oak using tree stem taper equations. Scientific Bulletin of National University of Life and Environmental Sciences of Ukraine, 288, 6-17. Retrieved from http://journals.nubip.edu.ua/index.php/Lisivnytstvo/ article/view/12722] (in Ukrainian)

Биченко В.Б., Миронюк В.В. (2019). Особливості моделювання твірної поверхні стовбурів дуба звичайного. Науковий вісник НЛТУ Украӥни, 29(5), 69-74. [Bychenko, V. B., \& Myroniuk, V. V. (2019). Some peculiarities of stem taper modelling of common oak trees. Scientific Bulletin of Ukrainian National Forestry University, 29(5), 69-74. https://doi.org/10.15421/40290514] (in Ukrainian)
ДСТУ 4020-2-2001. Лісоматеріали круглі та пиляні. Методи обмірювання та визначення об'ємів. Частина 2. Лісоматеріали круглі (pr EN 1309-2: 1998). [Чинний від 2001-07-01]. Вид. офіційне. Київ: Держстандарт України [DSTU 4020-2-2001 (2001). Round and sawn timber. Method of measurement of dimensions. Part 2: Round timber. [Effective from July 01.2001]. Official edition. Kyiv: Ukraine's Derzhstandart] (in Ukrainian)

ДСТУ ЕN 1316-1:2019. Лісоматеріали круглі листяні. Класифікаиія за якістю. Частина 1. Дуб та бук. (EN 1316-1:2012, IDT). (Чинний від 202101-01). Вид. офіційне. [DSTU EN 1316-1:2019 (EN 1316-1:2012, IDT) Hardwood round timber. Qualitative classification. Part 1: Oak and beech. [Effective from January 01.2021. Official edition] (in Ukrainian)

ДСТУ ЕN 1315-1-2001 Класифікачія за розмірами. Частина 1. Лісоматеріали круглі листяні. (EN 1315-1:1997, IDT). [Чинний від 2002-01-01]. Вид. офіційне. Київ: Технічний комітет зі стандартизації [DSTU EN 1315-1:2001 (EN 1315-1:1997, IDT). (2002). Dimensional classification - Part 1: Hardwood round timber. [Effective from January 01.2003]. Official edition. Kyiv: Technical Committee for Standardization] (in Ukrainian)

ГОСТ 2708-75. Лесоматериалы круглые. Таблииы объемов. Москва: Издательство стандартов, 1977. [GOST 2708-75. (1975). Round timber. Tables volumes, from 01 Jan 1977. Moscow: Standart Publishing House] (in Russian)

ГОСТ 9462-88. Лесоматериалы круглые лиственных пород, размеры и технические требования: Москва: Издательство стандартов, 1988. [GOST 9462-88. Roundwood timber of deciduous species. Technical specifications, from 01 Jan 1990. Moscow: Standard Publishing House] (in Russian)

GOST 3243-88. Дрова. Технические условия. Москва: Издательство стандартов, 1989. [Firewood. Technical specifications, from 01 Jan 1990. Moscow: Standart Publishing House] (in Russian)

Лісотаксаційний довідник (2020). А.М. Білоус, С.М. Кашпор, В.В. Миронюк, В.А. Свинчук, O.М. Леснік [Forest inventory handbook. (2020). Bilous, A.M., Kashpor, S.M., Myroniuk, V.V., Svinchuk, V.A., Lesnik, O.M. Kyiv] ISBN 978-966-981403-6 (in Ukrainian)

Никитин К.Е., Швиденко А.З. (1978) Meтоды $u$ техника обработки лесоводственной информациии. Москва: Лесная промышленность. 271 с. [Nikitin, K.E., \& Shvidenko, A.Z. (1978). Methods and technique of data processing in forestry. Moscow: Forest industry] (in Russian)

Слиш О. А., Пастернак В. П. (2018). Нормативи для визначення запасу і розмірно-якісної структури стиглих і перестійних порослевих дубових деревостанів. Лісівництво і агролісомеліорація, 132, 41-47. [Slysh, O.A., \& Pasternak, V.P. (2018). Standards for determining of growing stock and dimensionalqualitative structure of mature and overmature coppice oak forest stands. Forestry and forest melioration, 132, 
41-47. https://doi.org/10.33220/1026-3365.132.2018.41] (in Ukrainian)

Слиш О.А., Солодовник В.А., Букша М. I. (2014). Методи дистанційного вимірювання та моделювання профілів стовбурів для встановлення їхньої сортиментно-гатункової структури. Лісівниuтвво і агролісомеліорачія, 124, 42-46. [Slysh, O.A., Solodovnik, V.A., \& Buksha, M.I. (2014). Methods of remote measurement and modeling of stem profiles to evatuate their assortment and quality structure. Forestry and forest melioration, 124, 42-46. http://nbuv.gov.ua/ UJRN/lisam_2014_124_8] (in Ukrainian)

ТУУ 56.196-95. Деревина дров'яна для технологічних потреб. [Чинний від 1995-01-26]. Київ: Стандарти [TCU 56.196-95. (1995). Fuelwood for technological needs, from 26 Jan 1995. Kyiv: Standarty] (in Ukrainian)

ТУУ-00994207-005:2018. Деревина дров'яна. Класифікачія, облік, технічні вимоги [TCU-00994207005: 2018. Fuelwood. Classification, accounting, technical requirements. Retrieved from http://www.mdoffice.com. ua/pdf/tehnichni_umovi_1908021524.pdf]

Castle, M., Weiskittel, A., Wagner, R., Ducey, M., Frank, J., \& Pelletier, G. (2017) Variation in stem form and risk of four commercially important hardwood species in the Acadian Forest: implications for potential sawlog volume and tree classification systems. Canadian Journal of Forest Research, 47, 11. https://doi.org/10.1139/cjfr-2017-0182

Field-Map stem analyst (FMSA). URL: https://www. fieldmap.cz/?page $=$ fmsa

Kozak, A. (2004). My last words on taper equations. The Forestry Chronicle, 80(4), 507-515. https://doi. org/10.5558/tfc $80507-4$

Riemer, T., von Gadow, K., \& Sloboda, B. (1995). Ein Modell zur Beschreibung von Baumschaften. Allgemeine Forst-und Jagdzeitung, 166(7), 144147. [Riemer, T., von Gadow, K., \& Sloboda, B. (1995). A model to describe tree structures. General forest and hunting newspaper. Allgemeine Forst-und Jagdzeitung, 166(7), 144-147] (in Germany)

Socha, J., Netzel, P., \& Cywicka, D. (2020). Stem Taper Approximation by Artificial Neural Network and a Regression Set Models. Forests, 11(1), 79. https:// doi.org/10.3390/f11010079

\section{Dimensional and qualitative structure of Quercus robur L. trunks in stands of coppice origin of the Left-Bank Forest-Steppe of Ukraine}

\section{V.P. Pasternak', O. A. Slysh², V.V. Nazarenko³}

One of the important tasks of the production activity of forestry enterprises in Ukraine is to determine the structure of operational forests. In the current conditions, part of the regulatory framework, which was developed in previous years to address these issues, has partially lost relevance because of new standards adopted.

The experimental data are presented by the results of measuring 256 model oak trees on 28 temporary sample plots in premature, mature and overmature oak stands of coppice origin of the Left-Bank Forest-Steppe. To obtain data on the distribution of industrial timber by quality and size classes, we used the algorithm of conditional bucking of model trees and implemented it in the Field-Map Stem Analyst. The volume of the merchantable part of the trunks was calculated in the bark and without the bark sequentially, from the base to the top of the trunk, according to the requirements for the appropriate quality class. The classification of logs by quality was carried out both according to the standards in force until 2019 (hereinafter - GOST) and according to the new ones, which came into force in 2019 (DSTU).

The closest linear correlation is established for absolute values of volumes of qualitative categories of timber with volume of a trunk in bark. This dependence takes into account the impact on the yield of timber qualitative categories (not only diameter but also other biometric indicators of the trunk).

Data on the dimensional structure of industrial timber were summarized according to a method based on the study of patterns of distribution of the volume by dimensional classes in relative terms. According to the results of the analysis, a close dependence of the relative indicators of trunk timber dimensional structure by DBH was revealed.

On the basis of the developed mathematical models the tables of distribution of volume of industrial timber of merchantable oak trunks on dimensional classes of average diameter without bark are made.

According to the research results the average yield of industrial timber for oak stands of coppice origin of the Left-Bank Forest-Steppe is $58.6 \%$ (according to GOST), although the experimental data have trunks with a high share of industrial timber (up to $74.3 \%$ ). The increase in the average value of the share of industrial timber from $58.6 \%$ (according to GOST) to $68.0 \%$ (according to DSTU) was recorded mainly in trunks with a minimum length of the industrial part. The yield of industrial timber for such trunks increased due to the transition of the volume of some assortments classified according to GOST to technological fuelwood, to

Volodymyr P. Pasternak - Full Member of the Forestry Academy of Sciences of Ukraine, Doctor habil. (agricultural sciences), professor. Ukrainian Research Institute of Forestry and Forest Melioration named after G. M. Vysotsky, Pushkinska str., 86, Kharkiv, 61024, Ukraine. Tel.: +38-057-707-80-44. E-mail: pasternak65@ukr.net ORCID: https:// orcid.org/0000-0003-1346-1968

Olexandr A. Slysh - PhD, State Enterprise "Konotop Forestry", Konotopskih partizan str., 97, Konotop, 41605, Ukraine. Tel.: (05447) 6-62-38 E-mail: slysh_oleksandr@ukr.net

Vitalii V. Nazarenko - PhD, Faculty of Forestry, Department of Forest Management, Forest Exploitation and Life Safety, "Dokuchaevske-2", Kharkiv district, Kharkiv region, 62483, Ukraine. Tel.: +38-057-299-76-80. Tel.: +38-0572-99-76-80. E-mail: flg@ knau.kharkov.ua 
quality category $\mathrm{D}$ of industrial round timber according to the new DSTU.

To verify the developed tables, the data on final felling of 2019-2020 in SE "Konotop Forestry" and SE "Krasnopillia Forestry" were used. The comparison shows that the nature of the distribution by dimensional classes is similar. According to the tables, as a rule, the share of round timber of larger diameter is slightly higher, but the difference is insignificant.

The developed distribution tables make it possible to predict the yield of industrial timber for oak stands of coppice origin of the Left-Bank Forest-Steppe with sufficient accuracy according to the new European standards and to divide it into dimensional classes.

Key words: round timber; dimensional classes; bucking; trunk tape.

\section{Размерно-качественная структура стволов Quercus robur L. в древостоях вегетативного происхождения Левобережной Лесостепи Украины}

\section{В.П. Пастернак' , А. А. Слиш², В. В. Назаренко ${ }^{3}$}

Одна из важных задач производственной деятельности лесхозов Украины - определение структуры лесосечного фонда. В нынешних условиях часть нормативной базы, которая была разработана в предыдущие годы для решения этих задач, частично потеряла актуальность из-за принятия новых стандартов.

Экспериментальные данные представлены результатами измерений 256 модельных деревьев дуба черешчатого на 28 временных пробных площадях в приспевающих, спелых и перестойных дубняках порослевого происхождения Левобережной Лесостепи. Для получения данных о распределении деловой древесины по классам качества и толщины

Пастернак Владимир Петрович - академик Лесной академии наук Украины, доктор сельскохозяйственных наук, профессор. Украинский научно-исследовательский институт лесного хозяйства и агролесомелиорации им. Г.Н. Высоцкого, ул. Пушкинская, 86, Харьков, 61024, Украина. Тел.: +38-057-707-80-44. E-mail: pasternak65@ukr.net ORCID: https://orcid.org/00000003-1346-1968

Сльиш Александр Анатольевич - кандидат сельскохозяйственных наук, лесничий Новомутинского лесничества ДП «Конотопское лесное хозяйство», ул. Конотопских партизан, 97, Конотоп, Сумская область, 41605, Украина. Тел.: (05447) 6-62-38 E-mail: slysh_oleksandr@ukr.net

Назаренко Виталий Васильевич - кандидат сельскохозяйственных наук, доцент кафедры лесоуправления, лесоэксплуатации и безопасности жизнедеятельности Харьковского национального аграрного университета им. В.В. Докучаева, «Докучаевское - 2», Харьковский район, Харьковская область, 62483, Украина. Тел.: +38-0572-99-76-80. E-mail: flg@knau.kharkov.ua нами использован алгоритм условной раскряжевки модельных деревьев и реализован в Field-Map Stem Analyst. Объем ликвидной части стволов рассчитан в коре и без коры последовательно, от основы до вершины ствола, согласно требованиям соответствующего класса качества. Классификация бревен по качеству проведена как по действующим до 2019 г. стандартам (далее - ГОСТ), так и по новым, вступившим в силу в 2019 г. (ДСТУ).

Наиболее тесная линейная зависимость установлена для абсолютных значений объемов качественных категорий древесины от объема ствола в коре. Эта зависимость учитывает влияние на объем качественных категорий древесины не только диаметра, но и других биометрических показателей ствола.

Данные о размерной структуре деловой древесины обобщены по методике, основанной на изучении закономерностей распределения объемов деловой древесины по классам толщины в относительном выражении. По результатам анализа выявлена тесная зависимость относительных показателей размерной структуры древесины ствола от диаметра на высоте 1,3 м.

На основе разработанных математических моделей составлены таблицы распределения объемов деловой древесины деловых стволов дуба черешчатого по классам толщины по среднему диаметру без коры.

По результатам наших исследований, для дубовых насаждений вегетативного происхождения Левобережной Лесостепи средний выход деловой древесины составляет 58,6\% (по ГОСТу), хотя в экспериментальных данных есть стволы с высокой долей деловой древесины (до 74,3\%). Увеличение среднего значения доли деловой древесины с 58,6\% (по ГОСТу) до 68,0\% (по ДСТУ) зафиксировано в основном для стволов с минимальной длиной деловой части. Выход деловой древесины для таких стволов увеличился за счет включения объема части сортиментов, классифицируемых по ГОСТу, как технологические дрова, в категорию качества D круглого леса деловой древесины по новым ДСТУ.

Для проверки разработанных нормативов использованы данные о рубках главного пользования на 2019-2020 гг. в ГП «Конотопский лесхоз» и ГП «Краснопольский лесхоз». Сравнение показывает, что характер распределения по классам толщины аналогичен. По таблицам, как правило, доля бревен большего диаметра несколько выше, но разница незначительная.

Разработанные таблицы распределения дают возможность с достаточной точностью прогнозировать урожай деловой древесины дубовых насаждений вегетативного происхождения Левобережной Лесостепи по новым европейским стандартам и разделить его по классам толщины.

Ключевые слова: лесоматериалы круглые; классы толщины; раскряжевка; образующая ствола. 